\title{
Survey of the irp2 Gene Among Yersinia pestis Strains Isolated During Several Plague Outbreaks in Northeast Brazil
}

\author{
Alzira MP de Almeida ${ }^{\circ}$, Annie Guiyoule, Nilma C Leal*, Elisabeth Carniel ${ }^{+}$
}

\author{
Laboratoire des Yersinia, Institut Pasteur, 28 Rue du Dr. Roux, 75724 Paris Cedex 15, France *Centro de Pesquisas \\ Aggeu Magathães - FIOCRUZ, Caixa Postal 7472, 52020-020 Recife, PE, Brasil
}

The irp2 gene codes for a $190 \mathrm{kDa}$ protein (HMWP2) synthesized when highly pathogenic Yersinia are grown under conditions of iron starvation. In this work, the presence of irp2 in strains of Y. pestis isolated from different hosts during several plague outbreaks in the foci of Northeast Brazil was studied. For this purpose, 53 strains were spotted onto nylon filters and their DNA was hybridized with the A13 probe which is a $1 \mathrm{~kb}$ fragment of the irp2 coding sequence. All strains except two hybridized with the probe. However, when the initial stock culture of these two strains were analyzed, they both proved to be positive with the A13 probe, indicating that the locus was lost after subcullure in vitro but was always present in vivo. To examine the degree of conservation of the chromosomal fragment carrying irp2 among Brazilian strains, the hybridization profiles of 15 strains from different outbreaks, different hosts and different foci were compared. The hybridization profiles of these strains were all identical when their DNA was digested with either EcoRI, $\mathrm{EcoRV}$ or AvalI, indicating that the restriction sites surrounding the irp2 locus are very well conserved among Northeast Brazilian strains of Y. pestis. Altogether, these results suggest that the irp2 chromosomal region should be of prime importance for the bacteria during their multiplication in the host.

Key words: irp2 - chromosome - deletion - Yersinia pestis - iron - plague - Brazil

Yersinia pestis, the etiologic agent of plague, is a gram-negative bacterial pathogen, transmitted from rodents to rodents by fleas. Although the plague reservoir is the rodent, the disease can also affect humans (Poland \& Barnes 1979). The plague bacillus was introduced into Brazil during the last pandemic and persisted in rural areas, mainly in the Northeastern region, where several $Y$. pestis foci are still active nowadays (WHO 1965, Almeida et al. 1981, 1985, 1989). These foci share similar climatic conditions, rodent hosts and flea vectors. The field rodent Bolomys lasiurus (Zygodontomys lasiurus pixuna) and its fleas Polygenis spp., are the main animal reservoir and vector involved in the epizootics, but other species of rodents and fleas can also be responsible for plague outbreaks (Karimi et al: 1974a, b, c, Almeida et al. 1981, 1985, 1989). Cycles of plague activity have a periodicity of 5-10 years, with quiescent periods between each outbreak (WHO 1965, Almeida et al. 1981).

Many attempts have been made to find some differences among $Y$. pestis strains isolated from these foci but it has not been possible to link the

\footnotetext{
- Research fellow, Brazilian Research Council (CNPq).

${ }^{+}$Corresponding author

Received 13 May 1993

Accepted 19 November 1993
}

geographical origin, the type of host or the period of isolation of the isolates to a peculiar phenotypic or genetic trait.

Virulence in $Y$. pestis, depends on the synthesis of products encoded by chromosomal and plasmid genes (Brubaker 1991). Carniel et al. (1987) demonstrated that highly pathogenic Yersinia ( $Y$. pestis, Y. pseudotuberculosis and $Y$. enterocolitica biotype 1B) produce high molecular weight proteins (HMWPs) under conditions of iron starvation. The synthesis of the $190 \mathrm{kDa}$ protein (HMWP2) is encoded by the irp 2 chromosomal gene which is present in the highly pathogenic species only (Carniel et al. 1989, Almeida et al. 1993). This gene is absent from the non pathogenic or low pathogenicity strains and therefore could be used as a new genetic marker of high pathogenicity phenotype in Yersiniae (Carniel et al. 1991). The irp2 locus is located on an unstable chromosomal fragment, which can delete spontaneously in $Y$. pestis and $Y$. pseudotuberculosis. Loss of the gene is obtained by repeated subcultures of $Y$. pestis in vitro (Almeida et al. 1993) and is accompanied by a marked reduction in the bacterial pathogenicity (Carniel et al. 1991).

In this work, the presence of the irp2 gene among Brazilian $Y$. pestis strains was studied and the hybridization profiles of the chromosomal segments carrying this gene were com- 
pared. We demonstrate here for the first time that all the strains studied harbored the irp 2 locus upon primary isolation and, as found for strains of other geographical origins, that the gene could be lost after subcultures in vitro. The restriction profiles using three different enzymes were compared and were found to be all identical, indicating a high stability of the corresponding restriction sites in the irp2 region.

\section{MATERIALS AND METHODS}

Bacterial strains and growth conditions - The 53 Brazilian $Y$. pestis strains used in this study are listed in the Table. They were isolated from human patients, rodents, and fleas in the plague foci of Northeast Brazil between 1967 and 1986 (Karimi et al. 1974a, Almeida et al. 1981, 1985, 1989). The strains were named $P$. (for plague), followed by the name of the city (i.e. EXU or GRS) or the states (BA or PB), where the laboratories which isolated the strains were settled. Unless otherwise indicated, bacteria were routinely grown overnight at $28^{\circ} \mathrm{C}$ in peptone broth or on Blood Agar Base (Difco) for $48 \mathrm{hr}$. Each isolate was stabbed on duplicate Blood Agar Base (Difco) tubes and kept at $+4^{\circ} \mathrm{C}$. Care was taken to maintain one of the tubes as the original stock culture and to avoid subcultures. The $Y$. pestis vaccine strain EV76 was shown to be Irp2- (Carniel et al. 1987) and therefore was used in this study as a negative control. $Y$. enterocolitica strain Ye8081 (serotype O:8), $Y$. pseudotuberculosis strain IP32790 (serotype 1) and $Y$. pestis strain $6 / 69$ are all $\operatorname{Irp} 2+$ and the two formers have a different EcoRI hybridization profile with the Cla 8 probe (Almeida et al. 1993). They were used as positive controls for Southern hybridizations.

Chemicals - Coomassie brilliant blue, agarose and ethidium bromide were purchased from Sigma chemical corp., St Louis, Mo. Nylon filters (Hybond N.), Random priming kit, $\left[{ }^{35} \mathrm{~S}\right]$ dATP were obtained from Amersham Corp. (Arlington Heights, III.). Restriction endonucleases $E c o$ RI, EcoRV and $A v a I I$ were from Janssen Biochemica (Beerse, Belgium). Proteinase $\mathrm{K}$ was purchased from Boehringer Mannheim Biochemicals (Indianapolis, Ind.). Lambda DNAHindIII digests were obtained from New England Biolabs and were used as molecular weight markers. X-ray films XAR were purchased from Eastman Kodak Co., Rochester, N.Y.

DNA manipulations - Total DNA extractions and Southern Blots were performed as previously described (Carniel et al. 1989). For colony blotting, colonies grown on Blood Agar Base (BAB), were spotted onto nylon filters layered on $\mathrm{BAB}$ plates and incubated overnight at $28^{\circ} \mathrm{C}$. Bacterial lysis, DNA denaturation and hybridization were carried out as described elsewhere (Almeida et al. 1993). Two probes were used for this study: a $1 \mathrm{~kb}$ fragment (A13) of the coding sequence of the irp2 gene (Carniel et al. 1989), or an $8 \mathrm{~kb}$ DNA segment (Cla8), carrying the entire irp2 gene and adjacent sequences (Carniel et al. 1992). Both probes were labelled by random priming using ${ }^{35} \mathrm{~S}$ dATP. The A13 probe was used for colony hybridizations and the Cla8 probe for Southern hybridizations (Southern 1975). The filters were prehybridized, hybridized and washed at $65^{\circ} \mathrm{C}$ as described elsewhere (Carniel et al. 1989). Y. pestis strain EV76 (Irp2-) was used as a negative control for colony hybridizations.

\section{RESULTS}

Study of the presence of $\operatorname{irp} 2$ among $53 \mathrm{Y}$. pestis Brazilian isolates - In a previous study, we found that $44.7 \%$ of the $Y$. pestis strains isolated from different countries in the world had lost the irp2 gene (Almeida et al. 1993). We wondered whether such loss occurred in vitro after repeated subcultures or whether irp2 deleted strains could be found in vivo. Since the strains used in the above publication were subcultured several time, it was not possible to answer this question and we concluded that the study of a large number of fresh isolates would be of great interest. The existence of well documented plague foci in the Northeast of Brazil and of an important collection of $Y$. pestis strains isolated at different times from various hosts and places prompted us to examine these isolates for the presence of the irp2 locus. 53 strains of $Y$. pestis were screened by colony blot with the A13 probe for the presence of irp2. A13 is an internal fragment of the irp2 locus and was used as a probe because the absence of sequences adjacent to the $\operatorname{irp} 2$ gene decreased the hybridization background. Only two strains (P.EXU 21 and P.EXU 424) did not harbor the irp2 locus (Irp2). However, when the original stock cultures of these two Irp2- strains were taken, both strains were found to be originally Irp $2+$. Therefore, these results clearly demonstrate that all the freshly isolated $Y$. pestis strains studied harbored the irp 2 locus. These data also show that the Brazilian isolates, similarly to the strains isolated from other parts of the world (Almeida et al. 1993), can lose the irp2 region after in vitro subcultures.

Clas hybridization profiles of $10 \mathrm{Y}$. pestis strains isolated during the same outbreak - In order to determine the degree of conservation of the EcoRI hybridization profile of the chromosomal $\operatorname{irp} 2$ region and to evaluate the potential 
TABLE

Yersinia pestis strains isolated in Northeast Brazil and used in this study

\begin{tabular}{|c|c|c|c|}
\hline Strains & Host (species) & Geographical origin & Year \\
\hline P. EXU 21 & Rodent (Rattus r. alexandrimus) & Exu & 1967 \\
\hline P.EXU 25 & Rodent (Bolomys lasiturus) & Exu & 1967 \\
\hline P.EXU 41 & Rodent (Rattus $r$, frugivorus) & Exu & 1967 \\
\hline P.EXU 56 & Rodent (Bolomys lasiurus) & Exu & 1967 \\
\hline P.EXU 77 & Flea (Polygenis) & Exu & 1967 \\
\hline P.EXU 138 & Flea (Polygenis) & Exu & 1967 \\
\hline P.EXU 146 & Flea (Polygenis) & Exu & 1967 \\
\hline P.EXU 160 & Rodent (Rattus r. alexandrimus) & Exu & 1967 \\
\hline P.EXU 184 & Human & Exu & 1967 \\
\hline P.EXU 185 & Human & Caruaru & 1967 \\
\hline P.EXU 196 & Human & Triunfo & 1967 \\
\hline P.EXU 306 & Flea (Pulex irritans) & Exu & 1969 \\
\hline P.EXU 310 & Flea (Pulex irritans) & Exu & 1969 \\
\hline P.EXU 424 & Rodent (Gallea spixii wellsi) & Exu & 1970 \\
\hline P.EXU 559 & Flea (Polygenis) & San Benedito & 1972 \\
\hline P.EXU 662 & Human & Exu & 1974 \\
\hline P.EXU 795 & Human & Aratuba & 1978 \\
\hline P.EXU 796 & Human & Aratuba & 1978 \\
\hline P.EXU 800 & Rodent (Rattus $r$ alexandrinus) & Triunfo & 1978 \\
\hline P.EXU 801 & Human & Ipu & 1978 \\
\hline P.EXU 805 & Human & Capistrano & 1978 \\
\hline P.EXU 806 & Rodent (Calomys callosus) & Aratuba & .1978 \\
\hline P.EXU 810 & Rodent (Bolomys lasiurus) & Natuba & 1979 \\
\hline P.EXU 811 & Rodent (Bolomys lasiurus) & Natuba & 1979 \\
\hline P.EXU 817 & Rodent (Oryzomys subflavus) & Natuba & 1979 \\
\hline P.EXU 819 & Flea (Polygenis) & Triunfo & 1979 \\
\hline P.EXU 820 & Rodent (Bolomys lasiurus) & Natuba & 1979 \\
\hline P.EXU 834 & Rodent (Bolomys lasiurus) & Guaraciaba Norte & 1979 \\
\hline P.EXU 843 & Rodent (Bolomys lasiurus) & Natuba & 1980 \\
\hline P.EXU 851 & Rodent (Bolomys lasiurus) & Natuba & 1980 \\
\hline P.EXU 860 & Rodent (Bolomys lasiurus) & Salgado S. Felix & 1982 \\
\hline P.GRS 1 & Rodent (Bolomys lasiurus) & Minas Gerais & 1983 \\
\hline P.GRS 2 & Rodent (Bolomys lasiurus) & Minas Gerais & 1983 \\
\hline P.BA 2 & Flea (Xenopsylla cheopis) & Bahia & 1984 \\
\hline P.BA 3 & Human & Bahia & 1984 \\
\hline P.PB 862 & Human & Solanea & 1986 \\
\hline P.PB 863 & Human & Barra Sta. Rosa & 1986 \\
\hline P.PB 864 & Rodent (Rattus r. frugivorus) & Solanea & 1986 \\
\hline P.PB 865 & Rodent (Bolomys lasiurus) & Solanea & 1986 \\
\hline P.PB 866 & Rodent (Rattus $r$. frugivorus) & Solanea & 1986 \\
\hline P.PB 868 & Rodent (Bolomys lasiurus) & Solanea & 1986 \\
\hline P.PB 869 & Rodent (Holochilus sciureus) & Solanea & 1986 \\
\hline P.PB 870 & Rodent (Bolomys lasiurus) & Solanea & 1986 \\
\hline P.PB 871 & Rodent (Bolomys lasiurus) & Solanea & 1986 \\
\hline P.PB 872 & Rodent (Bolomys lasiurus) & Solanea & 1986 \\
\hline P.PB 873 & Rodent (Oryzomys subflavus) & Solanea & 1986 \\
\hline P.PB 874 & Rodent (Rattus r. frugivorus) & Solanea & 1986 \\
\hline P.PB 875 & Rodent (Rattus r. frugivorus) & Solanea & 1986 \\
\hline P.PB 876 & Rodent (Rattus r. frugivorus) & Solanea & 1986 \\
\hline P.PB 877 & Rodent (Rattus r. frugivorus) & Solanea & 1986 \\
\hline P.PB 878 & Rodent (Oryzomys subflavus) & Solanea & 1986 \\
\hline P.PB 879 & Rodent (Oryzomys subflavus) & Solanea & 1986 \\
\hline P.PB 881 & Human & Remigio & 1986 \\
\hline
\end{tabular}

BA: Bahia, PB: Paraíba, GRS: Garanhuns.

of host-induced variations, the genomic DNAs from 10 strains isolated during the same outbreak but from different hosts, were extracted, digested with $E c o R I$, transferred to nylon membranes and hybridized with the Cla8 probe. The Cla 8 probe was used instead of the $A 13$ probe because it is an $8 \mathrm{~kb}$ DNA segment which covers a larger DNA region surrounding the irp2 locus. The same $16 \mathrm{~kb}$ EcoRI segment was recognized by the probe in all the strains tested (Fig. 1), indicating that the bacteria isolated during this outbreak were homogeneous regard- 


\section{$\begin{array}{llllllllllll}1 & 2 & 3 & 4 & 5 & 6 & 7 & 8 & 9 & 10 & 11 & 12\end{array}$}

Fig. 1 : southern hybridization with the $\mathrm{Cla} 8$ probe of $E c o \mathrm{RI}$ digested total DNA of 10 strains of Yersinia pestis isolated from different hosts during the same outbreak in Exu in 1967. Lines 1, P.EXU 21; 2, P. EXU 25; 3, P.EXU 41; 4 , P.EXU 56; 5, P.EXU 77; 6, P.EXU $138 ; 7$, P.EXU 146; 8 , P.EXU $160 ; 9$, P.EXU 184; 10, P.EXU 185; $11, Y$. enterocolitica $0: 8$ strain Ye808 $1 ; Y$. pseudotuberculosis I strain IP32790.

ing the irp2 DNA segment. The EcoRI hybridizing fragment had a size similar to that of $Y$. pseudotuberculosis and different from the two bands recognized by the $\mathrm{Cla} 8$ probe in $Y$. enterocolitica (Fig. 1). This result also shows that the type of host infected with $Y$. pestis (humans, rodents or fleas) did not affect the irp2 profile. These data could be expected since flea vectors, rodent reservoirs and humans all belong to the same epidemiological plague cycle.

Clas hybridization profiles of $15 \mathrm{Y}$. pestis strains isolated during different outbreaks - To determine whether the EcoRI fragment carrying irp2 was similar in all Brazilian $Y$. pestis strains isolated or whether some clonal diversity appeared with time or with the geographical area where the outbreak occurred, the genomic DNAs of 15 strains listed in the Table were digested with $E c o$ RI and hybridized with the Cla8 probe. As shown on Fig. 2A, all strains had a $16 \mathrm{~kb}$ hybridizing fragment. This pattern was similar to that previously found in various strains isolated in European, African and Asian countries (Almeida et al. 1993).

To further investigate the conservation of the restriction map of the irp2 region, the chromosomal DNAs of these strains were also digested with Avall or EcoRV and hybridized with the Cla8 probe. As shown on Fig. 2B, the probe recognized three AvaII restriction fragments of approximately $12,3.5$ and $1.5 \mathrm{~kb}$ in all strains tested. When the DNAs were digested with $E c o$ RV, two fragments of ca. 6 and $7 \mathrm{~kb}$ hybridized with Cla8 in all the strains (Fig. 2C). These results indicate that the EcoRI, $A v a \mathrm{II}$ and $E c o$ RV restriction sites were perfectly conserved in the segment carrying the irp2 locus among different Brazilian strains. The profile obtained with the

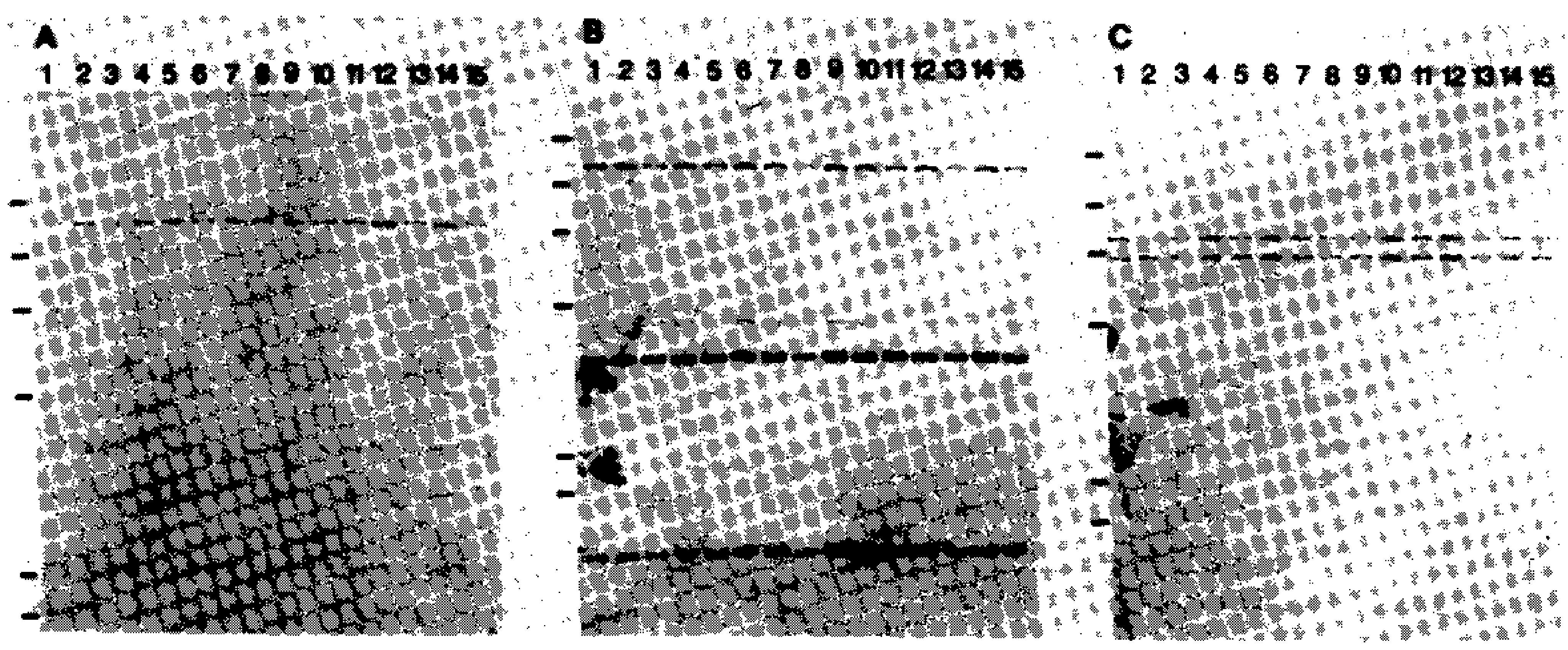

Fig 2: southern hybridization with the Cla8 probe of total DNA of 15 strains of Yersinia pestis isolated from different hosts during different outbreaks in Northeast Brazil. The DNAs were digested with either EcoRI (A), Avall (B) or EcoRV (C). Line 1, P.EXU 819; 2, P.EXU 559; 3, P.EXU 834; 4, P.EXU 800; 5, P.EXU 795; 6, P.GRS 2; 7, P.BA 2; 8, P.BA 3; 9, P.EXU 196; 10, P.EXU 310; 11, P.EXU 662; 12, P.EXU 796; 13, P.EXU 801; 14, P.EXU 805; 15 , P.GRS 1. Tick Marks on the left indicate the positions of the Lambda DNA-HindIII digests used as molecular weight markers: from top to bottom $23.1,9.4,6.5,4.3,2.3$, and $2.0 \mathrm{~kb}$. 
three different enzymes was also similar to that found in the $Y$. pestis 6/69 strain which was isolated in Madagascar (data not shown), suggesting that these profiles were not specific for the Brazilian strains but were conserved among $Y$. pestis strains of different geographical origins.

\section{DISCUSSION}

Between 1966 and 1986,881 Y. pestis strains have been isolated from: plague patients (155 strains), several species of rodents (490 strains) and fleas (236 strains), in Northeast Brazil (Karimi et al. 1974a, Almeida et al. 1981, 1985, 1989). We wondered whether the host exerted some selective pressure which would result in some genetic and/or phenotypic divergence among strains isolated from diverse species of rodents (Cavidae, Muridae and Cricetidae) or fleas.

Previous studies on Brazilian $Y$. pestis isolates concentrated on biochemical tests. Most of the isolates belonged to the $Y$. pestis Orientalis biovar (glycerol-negative, nitrate-positive), that was spread through the modern world during the last pandemic (Devignat 1951, WHO 1965, Karimi et al. 1974a). A few strains were glycerol-negative and nitrate-negative (an atypical, undescribed variant) (Karimi et al. 1974a) but no correlation could be established between the biovar of the strain and a geographical or host specificity.

Hudson et al. (1973) analyzed biochemical properties and total protein electrophoretic patterns of $17 \mathrm{Y}$. pestis strains isolated during a short period (1966 to 1967) from two plague foci in Northeast Brazil. They identified two groups of strains, based on the quantitative content of a protein which was latter recognized as the murine toxin (Tengerdy \& Hillam 1973). However, no correlation could be established between these two groups and the epidemiological characteristics of the strains.

More recently, Abath et al. (1989) carried out a study on the outer membrane protein profiles of 38 strains isolated during almost 25 years from several sources in various foci of the northeast. No major difference was found in the outer membrane protein profile of these strains.

Searching for other distinctive traits, the plasmid contents of 19 strains of $Y$. pestis collected during a plague outbreak in 1986, was investigated and compared to those of other strains previously isolated. All strains analyzed had a similar plasmid profile (Leal et al. 1989).

A very good correlation between the presence of the irp2 gene and the virulence of $Y$. pestis has been established (Carniel et al. 1991, Almeida et al. 1993). Therefore, the presence of the $\operatorname{irp} 2$ gene could be regarded as a marker of high virulence in $Y$. pestis. In a recent screening of $Y$. pestis strains isolated in several countries (but not in American plague foci) for the presence of $\operatorname{irp2}$, it was observed that the gene was absent from approximately $45 \%$ of the strains tested. However, it was not clear whether the gene was lost in vivo or after repeated subcultures in vitro.

In the present study, the $\operatorname{irp} 2$ gene was found in all but two strains tested (P. EXU 21 and P. EXU 424). However, original cultures of these strains were $\operatorname{Irp} 2+$, further illustrating that irp2 is easily lost in vitro upon repeated subcultures. This datum also indicates that all the bacteria harbored the irp2 locus in vivo and therefore strengthens the hypothesis that the presence of this gene should be of prime importance for the bacteria in its host, either as a growth factor or as a virulence determinant. Furthermore, the presence of the irp2 locus in all the strains tested indicate that they are all potentially highly pathogenic for humans. The attenuated vaccine strain EV76 which is non-pigmented and had lost the irp2 locus is not pathogenic upon subcutaneous injection but can persist for some time in the host. One can wonder whether the attenuated clinical forms or plague (pestis minor) may correspond to strains which have lost irp2. A study of the $Y$. pestis strains isolated from these patients would be of great interest.

Usually, regions of genomic DNA which do not carry important functions are subjected to frequent point mutations which lead to the loss or the acquisition of new restriction sites. The finding that the EcoRI, AvaII and EcoRV restriction sites on the irp 2 chromosomal segment were perfectly conserved among bacteria isolated from different geographical areas and different hosts over a period of 20 years further suggests that the irp2 DNA segment is of prime importance for $Y$. pestis, either for its survival or for the expression of virulence functions in its hosts.

\section{ACKNOWLEDGEMENTS}

To lain Old for correcting this manuscript.

\section{REFERENCES}

Abath FGC, Almeida AMP, Ferreira LCS 1989. Electrophoretic characterization of the outer membrane proteins of Yersinia pestis isolated in Northeast Brazil. Epidm Infect 103: 592-602.

Almeida AMP, Brasil DP, Leal NC, Melo MEB, Almeida CR 1989. Estudos bacteriológicos e sorológicos de 
um surto de peste no Estado da Paraiba, Brasil. $\mathrm{Mem}$ Inst Oswaldo Cruz 84: 249-256.

Almeida AMP, Carvalho FG, Almeida CR 1985. Isolamento da Yersinia pestis nos focos pestosos do nordeste do Brasil no período de 1966 a 1982. Rev Inst Med trop São Paulo 27: 207-218.

Almeida AMP, Guiyoule A, Guilvout I, Iteman I, Baranton G, Carniel E 1993. Chromosomal irp2 gene in Yersinia: distribution, expression, deletion and impact on virulence. Microb Pathogen 14: 9-21.

Almeida CR, Almeida AR, Vieira JB, Guida U, Butler T 1981. Plague in Brazil during two years of bacteriological and serological surveillance. Bull Whd Hlth Org 59: 591-597.

Brubaker RR 1991. Factors promoting acute and chronic diseases caused by Yersiniae. Clin Microbiol Rev 4: 309-324.

Carniel E, Guiyoule A, Guilvout I, Mercereau-Pujjaton O 1992. Molecular cloning, iron-regulation and mutagenesis of the $i r p 2$ gene encoding HMWP2, a protein specific for the highly pathogenic Yersinia. Mol Microbiol 6: 379-388.

Carniel E, Guiyoule A, Mercereau-Puijalon $O$, Mollaret HH 1991. Chromosomal marker for the "High Pathogenicity" phenotype in Yersinia. Contrib Microbiol Immunol 12: 192-197.

Carniel E, Mazigh D, Mollaret HH 1987. Expression of iron-regulated proteins in Yersinia species and their relation to virulence. Infect Immun 55: 277-280.

Carniel E, Mercereau-Puijalon O, Bonnefoy S 1989. The gene coding for the 190,000-dalton iron-regulated protein of Yersinia species is present only in the highly pathogenic strains. Infect Immun 57: 1211-1217.

Devignat R 1951. Variétés de l'espèce Pasteurella pestis. Nouvelle hyphothèse. Bull Wld Hllh Org 4: 247-263.
Hudson BW, Quan TJ, Sites VR, Marshall JD 1973. An electrophoretic and bacteriologic study of Yersinia pestis isolates from Central Java, Asia and the Western hemisphere. Am J Trop Med Hyg 22: 642-653.

Karimi Y, Almeida CR, Almeida AMP 1974b. La peste expérimentale chez les roungeurs du Brésil. Déductions épidémiologiques. Bull Soc Path Ex 67: 591-601.

Karimi Y, Almeida CR, Almeida AMP, Keyvanfar A. Bourdin M 1974a. Particularités des souches de Yersinia pestis isolés dans le nord-est du Brésil. Ann Inst Pasteur Microbiol 125A: 213-216.

Karimi Y, Eftekhari M, Almeida CR 1974c. Sur l’écologie des puces impliquées dans l'épidémiologie de la peste et le rôle éventuel de certains insectes hématophages dans son processus au Nord-est du Brésil. Bull Soc Path Ex 67: 583-591.

Leal NC, Almeida AMP, Ferreira LCS 1989. Plasmid composition and virulence-associated factors of Yersinia pestis isolates from a plague outbreak at the Paraiba state, Brazil. Rev Inst Med trop São Paulo 3/: 295-300.

Poland JD, Barnes AM 1979. Plague, p. 515-556. In J. F. Steele, CRC Handbook Series in Zoonoses, vol. 1, section A: Bacterial, rickettsial and mycotic diseases. CRC Press, Inc., Boca Raton/Fl.

Southem EM 1975. Detection of specific sequences among DNA fragments separated by gel electrophoresis. $J$ Mol Biol 98: 503-517.

Tangerdy RP, Hillam RP 1973. Quantitative differentiation of Yersinia pestis strains by their murine toxin and fraction 1 contents. Bull Wld Hlth Org 48: 279287.

WHO PAHO 1965. Plague in the Americas. Scientific Publication No 115: 44-68. Washington, DC. 